\section{Fachtagung "Landnutzung im Spiegel der Technikbewertung - Methoden, Indikatoren, Fall- beispiele"}

\section{Tagungsbericht von Matthias Plöchl und Ingo Ackermann, Institut für Agrartechnik Bornim}

Am 7. und 8. Dezember 1998 fand an der Universität Potsdam eine Fachtagung zum Thema Landnutzung im Spiegel der Technikbewertung - Methoden, Indikatoren, Fallbeispiele statt. Organisatoren dieser Tagung waren das Institut für Agrartechnik Bornim (ATB), Abteilung Technikbewertung und Stoffkreisläufe, und das Zentrum für Umweltwissenschaften der Universität Potsdam (ZfU). In einer Reihe von Vorträgen und Posterbeiträgen wurde die Thematik unter folgenden Zielstellungen, diskutiert:

- Bestandsaufnahme und Lösungsansätze zur Entwicklung des ländlichen Raums und zur Gestaltung einer zukunftsfähigen Landbewirtschaftung

- Vorstellung methodischer Konzepte der TA zur Identifikation erfolgversprechender Entwicklungspfade.

Die Tagung wurde durch Grußworte der Direktoren des ATB, Prof. Zaske, und des ZfU, Prof. Jänkel, als auch durch Vertreter des Bundesministeriums für Ernährung, Landwirtschaften und Forsten und der Brandenburger Ministerien für Umwelt, Naturschutz und Raumordnung sowie Ernährung, Landwirtschaften und Forsten eröffnet. In den Grußworten wurde deutlich, welche Bedeutung die Entwicklung des ländlichen Raumes innerhalb Europas, Deutschlands und Brandenburgs hat. Die Technikbewertung bzw. -folgenabschätzung kann hierzu wertvolle Beiträge liefern und die Definition und Anwendung von geeigneten Indikatoren ist dringlich.

Im Einführungsbeitrag wurden die Interaktionen zwischen Nachhaltigkeitsleitbildern und einer systemischen TA dargestellt. Ausgehend von den Forderungen und Schlußfolgerungen des Brundland-Berichts wurde der Anspruch formuliert, die intragenerationelle als auch die intergenerationelle Gerechtigkeit zu berücksichtigen und unter Beachtung ökonomischer, sozialer und ökologischer Aspekte zu definieren. Die anschließenden Beiträge ließen erkennen, daß es relativ schwierig ist, den Schnittpunkt dieser Dimensionen zu treffen. In der überwiegenden Mehrzahl der Präsentationen lag der Schwerpunkt auf der Berücksichtigung ökologischer Aspekte. Defizite in den vorgetragenen Konzepten waren vor allem im Hinblick auf die Berücksichtigung sozialer Indikatoren $\mathrm{zu}$ erkennen. Jedoch wurden von ostdeutschen Autoren die sozialen Aspekte oft angesprochen. Dies kann als eine Reflexion der Bedeutung und des dramatischen Strukturwandels der ländlichen Räume Ostdeutschlands gewertet werden. Insbesondere die Ausführungen über regionale Entwicklungskonzepte und die anschließenden Diskussionen machten deutlich, daß die Stabilisierung peripherer Regionen in Teilen Ostdeutschlands noch nicht bewältigt ist. Hieraus läßt sich folgender Handlungsbedarf für die zukünftige Methodenentwicklung ableiten: Definition geeigneter Kriterien zur Charakterisierung der sozialen Implikationen einer Technologie und Vorschläge zur Einbindung dieser Kriterien in ein komplexes Bewertungssystem.

Viele der methodischen Beiträge nahmen Bezug auf die im GEMIS-Modell entwickelte Prozesskettenanalyse zur Charakterisierung von Stoff- und Energieflüssen als Indikatoren für eine ökologische Bewertung. Weitere Indikatoren, die für eine Bewertung des ökologischen Zustandes genutzt werden, sind vor allem die Biodiversität und die Flächeninanspruchnahme. Auch in den gezeigten Fallbeispielen nahmen die Anwendungen des Stoffstrommanagements breiten Raum ein.

Die gezeigten Inhalte basieren im wesentlichen auf Modellberechnungen, unterstützt durch eine Vielzahl von Messungen. Die breite Verwendung des Computers als Hilfsmittel erlaubt die Übertragung der wissenschaftlichen Ergebnisse in praxisrelevante und direkt umsetzbare Anwendungen, die einem großen Kreis von Nutzern zugänglich sein sollten.

Deutliche Unterschiede zeigten sich in der räumlichen und zeitlichen Dimension der vorgetragenen Konzepte. Die Spanne reicht dabei von der Darstellung konkreter Versuchsanstellungen auf Betriebs- und Regionalebene bis hin 
zur globalen und intergenerationellen Betrachtung von Landnutzungskonzepten. An diesem Spektrum ist deutlich abzulesen, wie differenziert und vielgestaltig die TA-Landschaft ist.

Sowohl in den Grußworten, als auch in einem Teil der Beiträge wurde deutlich, daß die Thematik dieser Tagung einen wichtigen Beitrag zur nachhaltigen Entwicklung des ländlichen Raumes liefert. Es wird angestrebt. eine Fortsetzung dieser Tagung auch mit internationaler Beteiligung durchzuführen. Der Tagungsband zur Veranstaltung kann unter folgender Adresse bestellt werden: Institut für Agrartechnik Bornim (ATB), Max-Eyth-Allee 100, D14469 Potsdam (Frau Scheidemann: 03315699723 / Fax: -849).

$\gg$

\section{Beyond Sustainability: New Concepts from Amsterdam}

\section{by Krassimira Paskaleva, ITAS}

\section{Perspectives of Conference: Mission and Organization}

From 19 to 21 November 1998 about 160 scientists and policy-makers gathered in Amsterdam, the multicultural capital of the Netherlands, to participate in the international conference Beyond Sustainability: Integrating Behavioral, Economic, and Environmental Research. This multidisciplinary research conference was organized by the Netherlands Organization for Scientific Research (NWO) jointly with the Center of Environmental Science (Leiden University/NL) to conclude a five-year priority research program on 'Sustainability and Environmental Quality' coordinated by NWO. The purpose of the conference was to address the results of this research in the context of similar research programs elsewhere in Europe and around the world aiming to provide an opportunity for discussion and dissemination of the findings to a multi-disciplinary international audience. The foci of the first day, i.e. the main program set up the tone of the meeting.

Following the official opening ceremony, which included welcome and introductory speech by Reinder van Duinen (NWO, The Hague/NL), the bulk of the time during the first day of the conference was given to formally presenting and subsequently reviewing and discussing the three main sub-programs HOME, METALS, and RIVER, supplemented by presentations of their partner programs from Australia, Austria and Sweden, respectively. While the lightmotif, i. e. integrating behavioral, economic, and environmental research", was implicitly touched upon in the RIVER project presented by Eelco Van Beek of Delft University of Linkoping/NL, and also strongly emphasized by Helias Udo de Haes of CML, Leiden University/NL in his presentation of the METAL program, it was explicitly brought up by Tom Uiterkamp of IVEM, University of Gronongen/NL in HOME. In addition, while the overview presentations gave a good insight into the three programs, the partner programs provided additional international context to their framework and outcomes.

This overview was followed by three concurrent sessions during the second day of the conference focusing on: (a) Sustainable household management (b) Flows and accumulations of materials, and (c) Multinational river basin management. The chosen format, allowing the participants enough time after each session of open discussion, was recognized as a major advantage of the conference. A poster session at the end of the first day provided additional insights to the main research themes placing the concepts of sustainable development in various national and regional settings. Main poster topics included household management, land-use modeling of peripheral regions, environmental material flows, and environmental accounting. Consistent with recent foci of research and interests, a considerable attention was given particularly to the consumers' behavior in the context of sustainable consumption, changing life style patterns and the role of various shareholders in the process.

The three comprehensive scenarios of sustainable development presented at the concluding plenary session set up the final scene of the meeting. Three main alternative paths of development were outlined, involving: (a) Weak sustainability, where resources and capital are mutually replaceable with piecemeal environmental problem solving; (b) Maximization of 